\title{
PRA PRAKTIKUM: PENGEMBANGAN ENSIKLOPEDIA ALAT-ALAT LABORATORIUM BIOLOGI DI SMP/MTS
}

\author{
Supriyadi $^{1}$, Irna Lismawati ${ }^{2}$ \\ 1,2 UIN Raden Intan Lampung; supriadi@ radenintan.ac.id
}

\begin{abstract}
ABSTRAK
Penelitian ini bertujuan untuk: 1) Mengembangkan ensiklopedia alat-alat laboratorium biologi di SMP; 2) Menganalisis kelayakan produk yang dikembangkan mengacu hasil validasi ahli media, ahli materi, ahli pembelajaran, dan hasil uji coba produk. Prosedur penelitian merujuk desain Research and Development (R\&D). Langkah-langkah pengembangan dibatasi sampai tujuh tahap: analisis potensi masalah dan analisis kebutuhan, desain produk, validasi desain, revisi desain, uji coba produk dan revisi produk akhir. Instrumen penelitian berupa lembar validasi dan angket respon guru dan peserta didik. Hasil penelitian: 1) Buku ensiklopedia alat-alat laboratorium biologi untuk SMP/MTs.; 2) Kategori ensiklopedia bedasarkan ahli materi 83.92\%, ahli media $91.66 \%$, ahli pembelajaran $93.71 \%$. Respon guru terhadap produk sebesar $96.42 \%$ dan tanggapan peserta didik terhadap produk sebesar $81.87 \%$. sehingga ensiklopedia alatalat laboratorium biologi yang dikembangkan sangat layak digunakan sebagai sumber belajar.
\end{abstract}

Kata Kunci: Alat-Alat Laboratorium Biologi, Ensiklopedia

\begin{abstract}
This study aims to develop an encyclopedia of biological laboratory equipment in junior high schools and to analyze the feasibility of developed products referring to the validation of media experts, materials experts, learning experts, and result of product trials. The research procedure refers to Research and Development $(R \& D)$ design. However, in this research, the development steps are limited to 7 stages: analysis of potential and problem, information gathering, product design, design validation, design revisions, product trials and product revisions. The research instruments consist of validation sheets and questionnaire for teachers and pupils. The data were analyzed by a quantitative descriptive technique. The research resulted in an encyclopedia of biological laboratory tools for junior high school and assessment of the material expert $83.92 \%$, media expert $91.66 \%$, and learning expert $93.71 \%$. Teacher response to the product amounted to $96.42 \%$ and $81.87 \%$ for student. As conclusion, the encyclopedia of biological laboratory tools has a feasible development to be used as a learning resource.
\end{abstract}

Keywords: Encyclopedia, Biological Laboratory Equipment 


\section{PENDAHULUAN}

Pembelajaran sains dianalogikan sebagai sistem peredaran darah, praktikum ialah jantungnya. Sebab, belajar sains hakikatnya merupakan proses yang berkaitan erat dengan cara mencari tahu tentang fenomena alam secara sistematis untuk menghasilkan produk-produk sians: fakta-fakta, hukum-hukum, prinsip-prinsip dan teori-teori. Carin \& Sund (1989) dalam bukunya Teaching Science Trough Discovery juga mengungkap belajar sains adalah suatu sistem untuk memahami alam semesta melalui observasi dan eksperimen yang terkontrol.

Kegiatan praktikum memberi peluang kepada peserta didik untuk menguji dan mengaplikasi teori dalam kehidupan nyata ( real world). Praktikum juga dapat menarik minat siswa dalam mengembangkan konsep-konsep karena aktivitas praktikum memungkinkan siswa memperoleh pengalaman langsung untuk mengamati suatu fenomena. Pendek kata, praktikum mempunyai posisi penting dalam mewujudkan kebermaknaan belajar sains.

Woolnough and Allsop (Rustaman, dkk., 2003) menyebut praktikum dalam pembelajaran sains dilandasi oleh empat alasan pokok. Pertama, praktikum membangkitkan motivasi belajar peserta didik. Kedua, praktikum mengembangkan keterampilan dasar melakukan eksperimen. Ketiga, praktikum menjadi wahana belajar pendekatan ilmiah. Keempat, praktikum menunjang materi pelajaran. Senada dengan pendapat tersebut, Watson, Prieto, dan Dillon (1995) menekankan bahwa pendekatan praktikum memberikan pengalaman langsung, pengalaman pertama kepada siswa, sehingga mampu mengubah persepsi siswa tentang hal-hal penting. Oleh karena itu, kegiatan belajar yang sepantasnya pendekatan praktikum senantiasa diterapkan dalam pembelajaran sains.

Berbicara ihwal praktikum tentu tidak lepas dari ruang laboratorium. Keduanya bagai dua sisi mata uang. Laboratorium, dalam pengertian sempit, sering diartikan sebagai tempat berupa gedung yang dibatasi oleh dinding dan atap yang di dalamnya terdapat sejumlah alat dan bahan pratikum. Walaupun dalam definisi lain laboratorium juga dapat berupa ruang terbuka dan kebun botani (Sukarso, 2005).

Laboratorium ialah suatu tempat dimana aktivitas percobaan, praktikum dan penyelidikan dilakukan. Laboratorium berfungsi untuk melatih keterampilan- 
keterampilan, ruang interaksi antarpeserta didik, ruang untuk menguji teori-teori maupun temuan teknologi baru dan keterampilan-keterampilan baru, serta tempat display atau pameran. Lebih tegas lagi Peraturan Menteri Pendidikan Nasional No. 24 Tahun 2007 tentang standar Sarana dan Prasarana Sekolah, menyebut ruang laboratorium sains berfungsi sebagai tempat berlangsungnya kegiatan pembelajaran sains secara praktik yang memerlukan peralatan khusus (Aulia, 2008). Di samping itu, Ottander dan Grelsson (2006) menyatakan bahwa praktikum merupakan bagian yang sangat penting dalam pembelajaran sains. Kegiatan praktikum berfungsi menghubungkan teori/ konsep dan praktek, meningkatkan daya tarik atau minat siswa, dapat memperbaiki miskonsepsi, dan mengembangkan sikap analisis dan kritis pada siswa. Ini berarti, dalam pembelajaran sains aktivitas di laboratorium (praktikum) menjadi bagian integral dari proses belajar.

Kegiatan praktikum di sekolah-sekolah ternyata masih menghadapi banyak kendala. Berbagai hasil studi, baik kualitatif maupun kuantitatif melaporkan bahwa masalah utama yang ditemui oleh guru dalam melaksanakan praktikum antara lain kurangnya fasilitas laboratorium, khususnya bahan-bahan dan peralatan praktikum. Kompetensi guru dalam mengelola kegiatan laboratorium dinilai kurang. Rendahnya literasi laboratorium inilah yang secara otomatis membuat pelaksanaan praktikum di sekolah-sekolah kurang berkembang. Hasil penelitian dari Anggraeni (2001) dan Rustaman (2003) menemukan bahwa guru tidak memiliki pengetahuan dan keterampilan yang memadai dalam mengelola kegiatan laboratoriuum, bahkan untuk keterampilan tingkat paling dasar sekalipun. Malahan muncul semacam persepsi jarangnya pelaksanaan praktikum dalam pembelajaran karena banyak menyita waktu dan tenaga.

Hasil penelitian lain tentang praktikum yang bersumber dari Balitbang Depdiknas yaitu sekitar 51\% guru sains di SMP Indonesia tidak terampil menggunakan alat-alat laboratrium yang tersedia di sekolahnya. Banyak guru sains dan siswa yang tidak tahu, misalnya, nama suatu alat laboratorium, fungsinya untuk apa, dan bagaimana menggunakannya. Hal ini menandakan penguasaan keterampilanketerampilan dasar laboratorium guru masih rendah.

Berdasarkan hasil observasi di lapangan mengungkap bahwa sebagian besar guru dan peserta didik belum banyak mengenal peralatan laboratorium. Bahkan untuk 
sekadar menyebutkan nama dan menjelaskan fungsinya saja, peserta didik kesulitan. Siswa juga kebanyakan keliru menyebutkan nama dan cara menggunakan alat tersebut. Hal ini berakibat dalam satu kali praktikum atau percobaan akan memakan waktu yang cukup lama hanya untuk menjelaskan alat manakah yang akan digunakan untuk praktikum dan cara menggunakannya.

Tentu saja hambatan yang dihadapi guru untuk mengenalkan peralatan laboratorium biologi kepada peserta didik adalah tidak adanya alat itu sendiri. Minimnya kelengkapan alat-alat laboratorium menyulitkan guru untuk memperkenalkan peralatan laboratorium biologi kepada peserta didik dan peserta didik merasa tidak tertarik. Selain itu, di laboratorium-laboratorium sekolah sering tidak dilengkapi buku petunjuk penggunaan alat dan bahan. Oleh karena itu langkah peniliti selanjutnya yakni mengembangkan sebuah buku petunjuk kami menyebutnya Ensiklopedi yang dapat digunakan sebagai sarana untuk mengenalkan alat-alat laboratorium kepada siswa.

Ensiklopedia merupakan buku yang berisikan penjelasan atau uraian yang disusun sesuai abjad atau menurut susunan ilmu (Kamisa, 1997). Hubungannya dengan dunia pendidikan di Indonesia, ensiklopedia adalah salah satu buku pengayaan, yaitu buku yang berguna menambah wawasan, keterampilan, dan kepribadian. Ensiklopedia tidak sama dengan buku teks pelajaran, seperti buku pengayaan ensiklopedia tidak mempunyai kaitan secara langsung dengan kurikulum yang berlaku. Terkadang ensiklopedia disamakan dengan kamus. Perbedaaan yang mendasar kamus dan ensiklopedia adalah maka kamus hanya menjelaskan definisi setiap kata yang dilihat dari sudut pandang ilmu bahasa atau hanya menjelaskan kata-kata sinonim saja. Sedangkan ensiklopedia menyajikan penjelasan yang lebih mendalam, sehingga ensiklopedia yang dikembangkan berupa alat-alat laboratorium yang diperlukan sebagai sumber belajar untuk siswa mencari berbagai informasi tentang pengenalan alat laboratorium biologi dengan penampilan yang menarik.

\section{METODE PENELITIAN}

Penelitian dan pengembangan ini mengacu pada desain penelitian pengembangan Borg and Gall (2003) dan Dick and Carey (2009) meliputi tahaptahap:(1) research analysis, needs assessment, and proof of concept; (2) product 
planning and design; (3) preliminary product development; (4) preliminary field testing; (5) product revision; (6) main field testing; and (7) the final product revision. .

Data dalam penelitian dan pengembangan ini berupa data kuantitatif dan data kualitatif. Data yang berasal dari perumusan angka pada tahap pengembangan. Data kuantitatif ini berasal dari skor angket penilaian. Data yang berupa deskriptif produk yang berasal dari pendapat-pendapat para tim penguji yang berupa saran, kritik, serta tanggapan dapat pula berupa informasi. Data dikumpulkan dengan teknik observasi, wawancara, dan angket.

Observasi dilakukan saat melakukan analisis potensi dan masalah di laboratorium sekolah. Observasi yang dilakukan dengan cara obsevasi non-sistematis yang dilakukan oleh pengamat dengan tidak menggunkan instrumen pengamatan. Wawancara dilakukan secara terstruktur dengan pedoman wawancara. Wawancara bertujuan untuk mendapatkan informasi seberapa sering praktikum dilakukan pada mata pelajaran biologi, apakah peserta didik terampil dalam menggunakan peralatan praktikum yang ada di laboratorium pada saat praktikum. Angket (Quistionnaries) digunakan untuk memperoleh informasi dari responden dalam arti laporan tentang pribadinya atau hal-hal yang diketahui.Pada penelitian ini menggunakan angket check list $(\sqrt{ })$ sehingga pendidik dan peserta didik hanya memberikan tanda $(\sqrt{ })$ di kolomyang telah ditentukan.

Data penelitian dianalisis dengan teknik deskriptif kuantitatif. Data kuantitatif berbentuk angka-angka yang berasal dari validasi angket dan data kualitatif berbentuk desktiptif berupa informasi yang berasal dari validator. Angket kebutuhan pengembangan ensiklopedia peralatan laboratorium biologi dianalisis menggunakan data deskriptif kualitatif tanpa adanya perhitungan menggunakan angka. Angket validasi diisi oleh validator kemudian dianalisis menggunakan data kuantitatif dengan kategori sebagai berikut.

Tabel 1. Kategori Skala Likert

\begin{tabular}{lll}
\hline No & Analisis Kuantitatif & Skor \\
\hline 1. & Sangat layak & 4 \\
\hline 2. & Layak & 3 \\
\hline 3. & Tidak layak & 2 \\
\hline 4. & Sangat tidak layak & 1 \\
\hline
\end{tabular}


Pengukuran skala menggunakan interval, data interval dapat dianalisis dengan menghitung persentase jawaban pada angket ditiap item dengan menggunakan rumus:

$$
\mathrm{P}_{\mathrm{s}}=\frac{S}{N} \mathrm{X} 100 \%
$$

\section{Keterangan}

$\mathrm{P}_{\mathrm{s}}$ : Persentase

$\mathrm{S}$ : Jumlah jawaban responden dalam satu item

$\mathrm{N}$ : Jumlah nilai ideal dalam satu item

Setelah data diintervalkan maka selanjutnya data diinterpretasikan kedalam kategori kelayakan seperti Tabel 2. Pengembangan ensiklopedia peralatan laboratorium sains di SMP/MTs dikatakan layak apabila mendapatkan skor $\geq 51 \%$.

Tabel 2. Kriteria Kelayakan Produk

\begin{tabular}{cc}
\hline Skor Rata-Rata $(\%)$ & Kategori \\
\hline $76-100$ & Sangat layak \\
\hline $51-75$ & Layak \\
\hline $26-50$ & Kurang layak \\
\hline $0-25$ & Tidak layak \\
\hline
\end{tabular}

\section{HASIL PENELITIAN DAN PEMBAHASAN}

Penelitian ini mengembangkan produk ensiklopedia alat-alat laboratorium biologi untuk SMP/MTs. Ensiklopedia terbuat dari kertas HVS dengan ukuran A5 $(148 \times 210 \mathrm{~mm})$. Ensiklopedia peralatan laboratorium biologi berisi beberapa subbab yang ada di dalamnya ialah keselamatan kerja di laboratorium yang berisikan tata tertib laboratorium selama berada di laboratorium, alat proteksi diri selama berada di laboratorium yang jarang dipakai oleh peserta didik seperti jas laboratorium, masker, dan sarung tangan. Ensiklopedia ini menjelaskan alat-alat gelas yang berisikan mengenai peralatan laboratorium yang terbuat dari kaca namun terdapat pula peralatan laboratorium yang terbuat dari plastik namun diberikan keterangan mengenai alat laboratorium tersebut.

Alat-alat non gelas yaitu peralatan laboratorium yang tidak terbuat dari kaca, peralatan laboratorium non gelas terbuat dari porselin seperti cawan porselin mortal, lumpang, plat tetes, terbuat dari kayu seperti gegep kayu, rak tabung reaksi, kaki tiga, kawat kasa, pinset yang terbuat dari besi anti karat, ada pula alat laboratorium yang 
sekali pakai seperti kertas lakmus yang hanya bisa dipakai sekali dalam melakukan praktikum, kertas saring.

Ensiklopedia peralatan laboratorium juga memuat pengetahuan mengenai mikroskop dimulai dari bagian-bagian mikroskop serta deskripsinya, lalu cara penggunaan dan penyimpanan mikroskop yang umumnya tidak diketahui oleh siswa/i dijelaskan di dalam ensiklopedia, serta macam-macam mikroskop seperti mikroskop monokuler, binokuler, mikroskop pemindai elektron (SEM), mikroskop transmisi elektron (TEM). Pada halaman akhir dari ensiklopedia memuat pemeliharaan, penyimpanan, dan penggunaan bahan kimia yang berbahaya, pada umumnya bahan kimia berbahaya dipakai dalam beberapa praktikum namun bahan kimia yang berbahaya tersebut hanya dijelaskan dalam bentuk simbol yang tidak dimengerti oleh siswa/i maka dari itu bahan kimia yang berbahaya tersebut diuraikan di ensiklopedia ini dalam bentuk simbolis dan deskripsi secara singkat dan jelas.

Berikut ini beberapa fitur ensiklopedia yang dikembangkan.
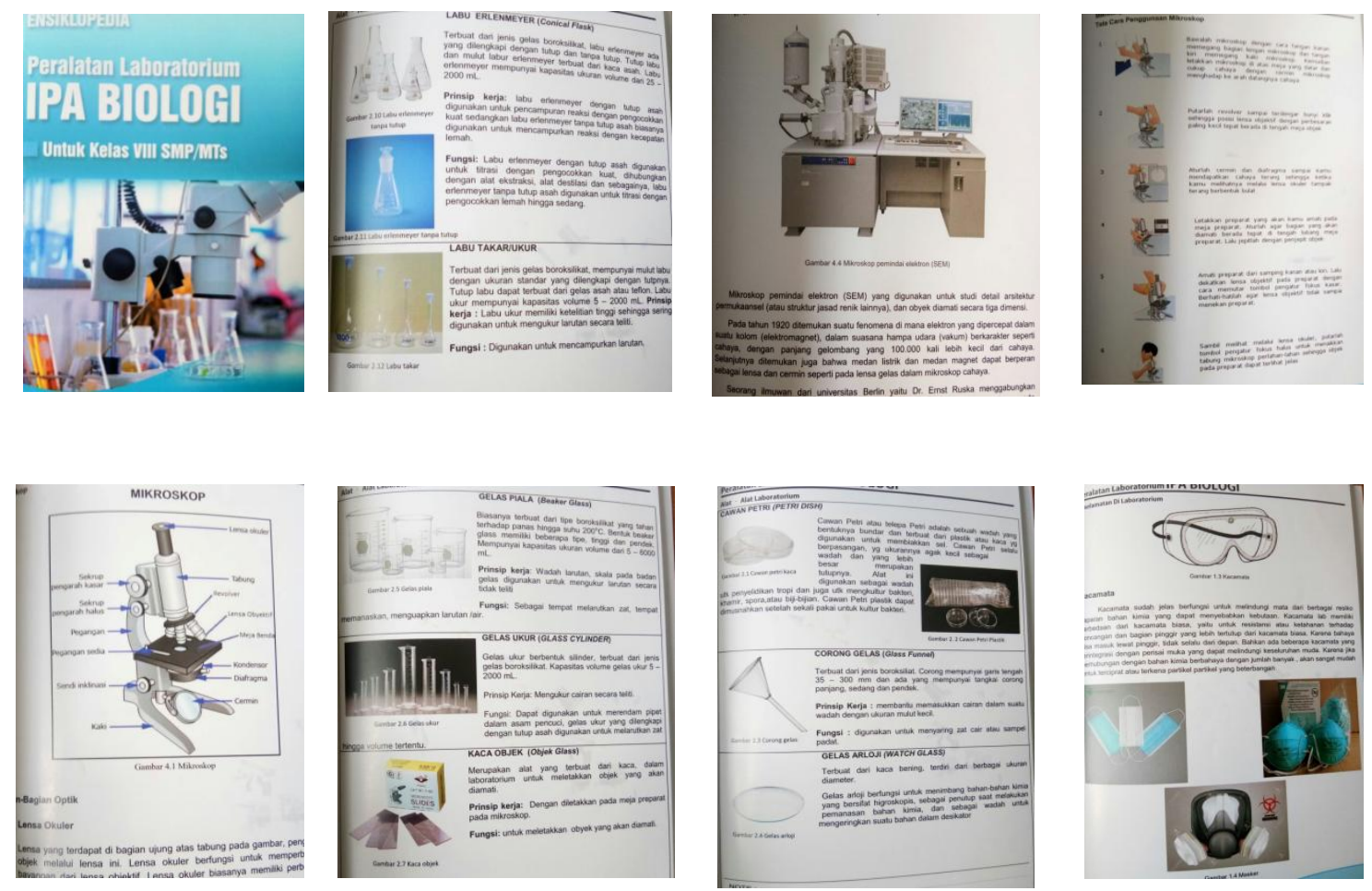

Gambar 1. Profil Ensiklopedia Alat-Alat Laboratorium

Data dalam penelitian ini dianalisis dengan pendekatan kuantitatif dan data kualitatif. Data kuantitatif merupakan yang berasal dari perumusan angka pada tahapan pengembangan, data ini berasal dari skor angket penelitian. Data kualitatif ialah data 
yang berupa deskriptif produk berasal dari pendapat-pendapat para tim penguji berupa saran, kritik, serta tanggapan serta informasi.

Data berasal dari para tim penguji, dengan memvalidasi produk dengan tujuan untuk mengetahui dan mengevaluasi secara sistematis instrumen dan media yang dikembangan sesuai dengan tujuan. Berikut adalah hasil validasi kelayakan oleh para ahli seperti pada Tabel 3, 4 dan 5 .

1. Validasi oleh ahli materi

Tabel 3. Hasil Validasi Uji Ahli Materi

\begin{tabular}{|c|c|c|c|c|c|}
\hline \multirow[t]{2}{*}{ Aspek } & \multirow{2}{*}{$\begin{array}{c}\text { Skor } \\
\text { Maksimal }\end{array}$} & \multicolumn{2}{|c|}{ Persentase $(\%)$} & \multicolumn{2}{|c|}{ Kriteria } \\
\hline & & Awal & Akhir & Awal & Akhir \\
\hline $\begin{array}{l}\text { Kesesuaian Materi } \\
\text { Dengan SK, KD Indikator } \\
\text { dan Tujuan Pembelajaran }\end{array}$ & 20 & $80 \%$ & $95 \%$ & $\begin{array}{l}\text { Sangat } \\
\text { Layak }\end{array}$ & $\begin{array}{l}\text { Sangat } \\
\text { Layak }\end{array}$ \\
\hline $\begin{array}{l}\text { Kesesuaian Ensiklopedia } \\
\text { Dengan Laboratorium } \\
\text { Biologi }\end{array}$ & 16 & $75 \%$ & $93.75 \%$ & $\begin{array}{l}\text { Sangat } \\
\text { Layak }\end{array}$ & $\begin{array}{l}\text { Sangat } \\
\text { Layak }\end{array}$ \\
\hline Kualitas Media & 8 & $75 \%$ & $100 \%$ & Layak & $\begin{array}{l}\text { Sangat } \\
\text { Layak }\end{array}$ \\
\hline Kualitas Media & 12 & $58.33 \%$ & $100 \%$ & Layak & $\begin{array}{l}\text { Sangat } \\
\text { Layak }\end{array}$ \\
\hline
\end{tabular}

2. Validasi ahli media

Tabel 4. Hasil Validasi Uji Ahli Media

\begin{tabular}{cccccc}
\hline Aspek & $\begin{array}{c}\text { Skor } \\
\text { Maksimal }\end{array}$ & \multicolumn{2}{c}{ Persentase (\%) } & \multicolumn{2}{c}{ Kriteria } \\
\cline { 3 - 6 } & 12 & $66 \%$ & $100 \%$ & Layak & Sangat Layak \\
\hline Kualitas Media & 16 & $68.75 \%$ & $81.25 \%$ & Layak & Sangat Layak \\
\hline $\begin{array}{c}\text { Efektivitas } \\
\text { Media }\end{array}$ & 16 & $50 \%$ & $100 \%$ & $\begin{array}{c}\text { Kurang } \\
\text { Layak }\end{array}$ & Sangat Layak \\
\hline $\begin{array}{c}\text { Teknik } \\
\text { Penyajian }\end{array}$ & 8 & & & & \\
\hline
\end{tabular}

3. Validasi Ahli Pembelajaran

Tabel 5. Hasil Validasi Uji Ahli Pembelajaran

\begin{tabular}{|c|c|c|c|c|c|}
\hline \multirow[t]{2}{*}{ Aspek } & \multirow{2}{*}{$\begin{array}{c}\text { Skor } \\
\text { Maksimal }\end{array}$} & \multicolumn{2}{|c|}{ Persentase (\%) } & \multicolumn{2}{|c|}{ Kriteria } \\
\hline & & Awal & Akhir & Awal & Akhir \\
\hline $\begin{array}{l}\text { Isi yang } \\
\text { disajikan }\end{array}$ & 32 & $65.56 \%$ & $90.62 \%$ & Layak & Sangat Layak \\
\hline Bahasa & 8 & $75 \%$ & $100 \%$ & Layak & Sangat Layak \\
\hline
\end{tabular}




$\begin{array}{llllll}\text { Waktu } & 12 & 75 \% & 100 \% & \text { Layak } & \text { Sangat Layak }\end{array}$

4. Respon Guru Biologi Terhadap Produk

Tabel 6. Hasil Validasi Guru Biologi

\begin{tabular}{c|c|c|c|c|c}
\hline \multirow{2}{*}{ Aspek } & \multirow{2}{*}{$\begin{array}{c}\text { Skor } \\
\text { Maksimal }\end{array}$} & \multicolumn{2}{|c|}{ Persentase (\%) } & \multicolumn{2}{c}{ Kriteria } \\
\cline { 3 - 6 } & & Awal & Akhir & Awal & Akhir \\
\hline Isi & 40 & $52.5 \%$ & $87.5 \%$ & Layak & Sangat Layak \\
\hline Kebahasaan & 16 & $62.5 \%$ & $75 \%$ & Layak & Sangat Layak \\
\hline
\end{tabular}

Data yang berupa deskriptif produk berasal dari pendapat para validator meliputi saran, kritik, serta tanggapan serta informasi mengenai produk. Pada penelitian ini divalidasi oleh 3 ahli penguji yaitu uji ahli materi, uji ahli media, uji ahli pembelajaran, adapun tanggapan guru biologi di sekolah dan tanggapan peserta didik terhadap produk. Ahli materi menilai tentang isi materi ensiklopedia peralatan laboratorium biologi materi yang digunakan mengenai peralatan laboratorium. Ahli materi yang menjadi validator dalam penelitian ini adalah ahli laboratorium Pendidikan Biologi. Data diperoleh dengan memberikan instrumen. Ahli materi memberikan penilaian, saran dan komentar terhadap isi materi peralatan laboratorium biologi. Setelah melakukan penilaian maka diketahui hal-hal yang perlu untuk direvisi.

Hasil produk awal diuji ahli materi mendapatkan kriteria layak pada produk awal terdapat beberapa saran untuk perbaikan produk ensiklopedia peralatan laboratorium biologi oleh ahli materi antara lain, penempatan kerja di laboratorium yang kurang tepat terdapat tambahan untuk deskripsi mengenai tata tertib labolatorium serta alat proteksi diri, memberikan informasi tambahan mengenai peralatan sekali pakai dan penambahan alat non gelas, memberikan pengetahuan tambahan mengenai macam-macam laboratorium dan bahan kimia berbahaya.

Produk ensiklopedia diperbaiki untuk mendapatkan produk akhir dan divalidasi kembali oleh uji ahli materi yang sama dengan instrumen yang sama guna melihat peningkatan mutu pada produk. produk akhir yang telah diperbaiki mendapatkan kriteria sangat layak dari validator ahli materi. Validasi media dilakukan oleh ahli media pembelajaran. Penilaian terhadap produk dengan mengisi lembar penilaian instrumen validasi pada masing-masing aspek penilaian yang terdiri dari tiga aspek dan 
masing-masing aspek terdapat beberapa pertanyaan dari 9 pertanyaan yang seluruhnya diisi oleh satu orang ahli media.

Hasil produk awal diuji ahli media mendapatkan kriteria layak namun terdapat saran perbaikan yang diberikan oleh validator ahli media antara lain tulisan pada produk ensiklopedia kecil sehingga tidak jelas untuk dibaca, gambar kecil sehingga kurang jelas untuk dilihat, diberikan tambahan berupa biodata penulis di dalam produk ensiklopedia, menambahkan kejelasan peserta didik yang dituju untuk produk ensiklopedia, memberikan kejelasan untuk setiap subbab yang ada. Produk ensiklopedia peralatan laboratorium diperbaiki dan kembali divalidasi oleh uji ahli media yang sama dan produk ensiklopedia peralatan laboratorium biologi mendapatkan kriteria sangat layak dari validator ahli media.

Validasi ahli pembelajaran dilakukan dengan menilai perangkat pembelajaran seperti silabus dan RPP. Angket penilaian silabus terdiri dari 3 aspek yang berisi 13 pertanyaan, lalu pada angket RPP terdiri dari 4 pertanyaan dan ada 11 pertanyaan yang akan diisi oleh ahli pembelajaran. Hasil validasi produk awal uji ahli pembelajaran (silabus) mendapatkan kriteria layak dengan saran dari validator ahli pembelajaran. Adapun saran dari validator ahli pembelajaran ialah pada kurikulum 2013 tidak mengenal standar kompetensi (SK), kurikulum 2013 hanya terdapat kompetensi inti (KI) dan kompetensi dasar (KD).

Produk ensiklopedia praktikum setelah divalidasi oleh ahli materi, media dan pembelajaran dan produk setelah diperbaiki. Selanjutnya produk diberikan kepada guru mata pelajaran biologi di sekolah tempat penelitian. Hal ini bertujuan untuk mengetahui respon guru terhadap produk yang dikembangkan. Respon guru biologi terdiri dari satu orang guru di tempat penelitian yaitu di SMP Negeri 9 Bandar Lampung. Adapun hasil dari respon guru mata pelajaran biologi terhadap produk yang dikembangkan.

Produk awal validasi guru biologi mendapatkan kriteria layak, produk awal diperbaiki dengan saran perbaikan oleh guru biologi. Saran perbaikan yang ada ialah, ensiklopedia dibuat semenarik mungkin sehingga siswa/i ingin membacanya. Produk ensiklopedia diperbaiki dan divalidasi kembali oleh guru biologi yang sama dan mendapatkan kriteria hasil sangat layak.

Uji coba dilakukan di SMP Negeri 9 Bandar Lampung pada kelas VIII responden sebanyak 35 siswa. Tujuan pelaksaan uji coba adalah untuk mengetahui 
tanggapan siswa terhadap ensiklopedia peralatan laboratorium biologi. Dalam uji coba langkah awal yamg dilakukan adalah mengenalkan produk ensiklopedia peralatan laboratorium biologi, kemudian peneliti menjelaskan bagaimana penggunaan ensiklopedia peralatan laboratorium biologi. Setelah melakukan langkah awal, langkah selanjutnya ialah memberikan angket penilaian tanggapan siswa terhadap produk yang dikembangkan. Untuk melihat kemandirian dan keaktifan siswa dalam melaksanakan praktikum maka peneliti melakukan praktikum dengan materi sistem gerak. Tanggapan siswa kelas VIII terhadap ensiklopedia peralatan laboratorium berjumlah 35 siswa setelah dihitung dan dicocokan dengan skala penilaian.

Pengembangan ensiklopedia peralatan laboratorium biologi membantu peserta didik dalam mengenal peralatan laboratorium biologi, membantu peserta didik mandiri dan aktif dalam kegiatan praktikum di sekolah. Peserta didik pada awalnya hanya mengetahui bentuk dari peralatan laboratorium yang sering dilihat namun tidak mengetahui nama dan fungsi dari alat tersebut. Setelah peserta didik membaca dan memahami isi dari ensiklopedia peralatan laboratorium biologi peserta didik jadi mengetahui nama alat dan fungsi dari peralatan laboratorium tersebut. Melaksanakan praktikum di sekolah peserta didik secara mandiri menyiapkan peralatan praktikum yang dibutuhkan sesuai dengan tuntunan praktikum yang ada serta aktif dalam melaksanakan praktikum.

Hal ini mengisyaratkan bahwa pengembangan ensiklopedia peralatan laboratorium biologi untuk peserta didik kelas VIII SMP/MTs sangat layak digunakan sebagai sumber buku yang baru bagi siswa sebagai pengetahuan baru mengenai peralatan laboratorium biologi. Ensiklopedia ini menjadi referensi sumber belajar yang menarik bagi siswa dalam mempelajari dan mengenal beragam peralatan laboratorium biologi sesuai jenis, fungsi maupun kegunaannya. Ensiklopedia ini dapat menumbuhkan minat dan kemandirian siswa untuk aktif dan terampil dalam melakukan kegiatan praktikum IPA biologi dengan menggunakan alat-alat laboratorium biologi.

\section{SIMPULAN}

Simpulan dari penelitian pengembangan ini adalah: ensiklopedia peralatan laboratorium biologi untuk SMP/MTs kelas VIII mendapatkan kualitas sangat layak untuk menjadi sumber belajar yang baru bagi peserta didik kelas VIII SMP/MTs. 
Beberapa saran sebagai berikut: 1) Ensiklopedia dapat dikembangkan kembali oleh guru secara berkelanjutan dengan materi yang berbeda; 2) Bagi pembaca, dapat melakukan pengembangan ensiklopedia yang lebih modern lagi dalam bentuk software agar ensiklopedia dapat mengikuti perkembangan era digital.

\section{DAFTAR PUSTAKA}

Anggraeni, S. (2001). Analisis Pembelajaran Biologi Molekuler di SMU Kodya Bandung. Makalah Penelitian. Bandung: FMIPA UPI

Carin, A.A. \& Sund, R.B. (1989). Teaching Science Through Discovery. Columbus: Merrill Publishing Company.

Dick, W. \& Carey, L. (2009). The Systematic Design of Instruction (7th ed.). Grenview, IL: Scott, Foresman and Company.

Gall, J., Borg. W., \& Gall, M. (2003). Educational Research: An introduction (7th ed.). Boston: Pearson Education.

Kamisa. (1997). Kamus Lengkap Bahasa Indonesia. Surabaya: Penerbit Kartika.

Ottander, C, \& Grelsson, G. (2006). Laboratory work: The Teachers' Perspective. Journal of Biological Education. 40(3), 113-118.

Permendiknas No. 24 Tahun 2007 Tentang Standar Sarana dan Prasarana.

Rustaman, N.Y., Yudianto, S.A., dan Rochintaniawati, D. (2003). Strategi Belajar Mengajar. Bandung: JICA IMSTEP: FPMIPA UPI.

Sukarso. (2005). Pengertian dan Fungsi Laboratorium. Diunduh dari http://wanmustafa. Wordpress.com/2011/06/12/pengertian-dan-fungsilaboratorium/

Watson, R., Prieto, T. \& Dillon, S.J., (1995). The Effect of Practical Work on Students' Understanding of Combustion. J. Research in Science Teaching. Vol 32, No. 5. 